\title{
Biology of Rhizobium trifolii Bearing the Hairy Root Plasmid
}

\author{
By GARY A. STROBEL, ${ }^{*}$ MORTEN HEIDE ${ }^{1} \dagger$ AND BILL M. HESS ${ }^{2}$ \\ ${ }^{1}$ Department of Plant Pathology, Montana State University, Bozeman, Montana 59717, USA \\ ${ }^{2}$ Department of Botany and Range Science, Brigham Young University, Provo, Utah 84601, \\ $U S A$
}

(Received 12 October 1985)

\begin{abstract}
We have transferred the hairy root plasmid (pRi) from Agrobacterium rhizogenes into Rhizobium trifolii. The plasmid fully expressed its root-inducing activity in the $R$. trifolii (pRi) transconjugant. Generally, the $R$. trifolii (pRi) transconjugant was unable to nodulate clover. However, occasionally a spontaneous mutant(s) of the $R$. trifolii (pRi) transconjugant arose which was capable of nodulating clover and of inducing root proliferation in a number of plant species. The mutant(s) induced significantly more nodules than the wild-type bacterium, but significantly less $\mathrm{N}_{2}$ was fixed by these nodules.
\end{abstract}

\section{INTRODUCTION}

Recently, we have introduced the Ri plasmid of Agrobacterium rhizogenes into Rhizobium meliloti (Strobel et al., 1985). The Ri plasmid is responsible for the induction of the hairy root syndrome in dicotyledonous plants (Moore et al., 1979; White \& Nester, 1980a, b). In order to accomplish the direct transfer of the Ri plasmid into $R$. meliloti, a mutant derivative of $A$. rhizogenes strain TR 105 was prepared by $\mathrm{Tn} 5$ transposon mutagenesis. This derivative carries a Tn5 insertion in its Ri plasmid which permits a much higher efficiency of transfer than that obtained with the wild-type Ri plasmid (B. Lam, unpublished). The $R$. meliloti transconjugants prepared by this procedure were unable to cause root proliferation in any of the dicotyledonous plants that were tested. However, the transconjugants were capable of nodulating alfalfa seedlings to a much greater extent than wild-type $R$. meliloti. The increased nodulation also resulted in significantly more $\mathrm{N}_{2}$ being fixed than by either the wild-type or antibiotic-resistant mutants of $R$. meliloti. Furthermore, there were no ultrastructural differences between the nodules produced by the wild-type $R$. meliloti and those produced by the transconjugants.

In this paper we report the construction and characteristics of Ri plasmid transconjugants of Rhizobium trifolii. The transconjugants differed in several ways from those of $R$. meliloti.

\section{METHODS}

Bacterial strains and culture conditions. The strains of Agrobacterium spp. and $R$. trifolii used are listed in Table 1 . All bacteria were grown on yeast extract/mannitol (YM) medium and the antibiotic concentrations used were as previously reported (Strobel et al., 1985). All bacteria used to inoculate plants were grown from single colonies.

Bacterial mating. Matings between $A$. rhizogenes and $R$. trifolii were done on sterile Millipore filters placed on nutrient agar medium. The $A$. rhizogenes donor (BL311), derived from TR105, contains only the Ri plasmid into which there is a Tn 5 insertion which permits a higher efficiency of transfer (B. Lam, unpublished; Strobel et al., 1985 ) and allows growth on a medium containing kanamycin. The $R$. trifolii recipient (LH3) is a spontaneous streptomycin- and rifampicin-resistant derivative of the wild-type $R$. trifolii strain 2067. Back mating of $R$. trifolii (pRi) transconjugants with Agrobacterium radiobacter NT1 was done as described above; however, selection of the $A$. radiobacter transconjugants, i.e. LH16, was done on an agrobacterium selective medium containing $500 \mu \mathrm{g}$ kanamycin $\mathrm{ml}^{-1}$ (Strobel \& Nachmias, 1985).

† Present address: Department of Plant Pathology, The Royal Veterinary and Agricultural University, Copenhagen, Denmark. 
Table 1. Bacterial strains

\begin{tabular}{|c|c|c|}
\hline Strain & Relevant characteristics* & Source \\
\hline \multicolumn{3}{|l|}{ A. rhizogenes } \\
\hline TR105 & Wild-type (producing roots) & L. Moore, Oregan Stat \\
\hline BL311 & $\begin{array}{l}\text { TR105(pRiTR 105-2:Tn5) } \\
\text { Kan', transfers pRi at high frequency (donor parent) }\end{array}$ & Our collection \\
\hline \multicolumn{3}{|c|}{ A. radiobacter } \\
\hline NT1 & $\begin{array}{l}\text { Derived from } A \text {. tumefaciens } \mathrm{C} 58 \\
\text { Lacks the } \mathrm{Ti} \text { plasmid }\end{array}$ & L. Moore, Oregon State \\
\hline LH16 & $\begin{array}{l}\mathrm{NT} 1 \text { (pRiTR } 105-2:: \operatorname{Tn} 5) \\
\text { Prepared by conjugation of } \mathrm{NT} 1 \text { and } R \text {. trifolii } \mathrm{LH} 11\end{array}$ & This paper \\
\hline \multicolumn{3}{|l|}{ R. trifolii } \\
\hline 2067 & Wild-type & USDA, Beltsville, Md. \\
\hline LH3 & $\begin{array}{l}\text { Spontaneous, two step, } \operatorname{Rif}^{r} \operatorname{Str}^{r} \text { derivative of strain } \\
2067 \text { (recipient parent) }\end{array}$ & This paper \\
\hline $\begin{array}{l}\text { LH11 } \\
\text { LH12 } \\
\text { LH11-Ro }\end{array}$ & $\begin{array}{l}\operatorname{Rif}^{r} \operatorname{Str}^{r} \mathrm{Kan}^{\mathrm{r}} \\
\text { Contain pRiTR105-2::Tn5 (pRi transconjugants) } \\
\text { Spontaneous mutant of LH11 } \\
\text { Produces numerous small nodules on clover }\end{array}$ & $\begin{array}{l}\text { This paper } \\
\text { This paper }\end{array}$ \\
\hline
\end{tabular}

Identification of bacteria. To ensure that the recipients of the $\mathrm{Ri}$ plasmid were really transconjugants, we compared the banding patterns of total soluble proteins separated by isoelectric focusing of the $R$. trifolii and $A$. radiobacter transconjugants to the proteins of the donor and recipient bacteria. Cultures $(200 \mathrm{ml})$ at late exponential phase were centrifuged at $10000 \mathrm{~g}$ for $15 \mathrm{~min}$ at $4{ }^{\circ} \mathrm{C}$. The supernatant liquid was discarded and the pellet resuspended in $50 \mathrm{ml} 50 \mathrm{~mm}$-potassium phosphate buffer $\mathrm{pH} 7.5$ made $0.14 \mathrm{M}$ with respect to sodium chloride. The bacterial cells were broken by sonication $(4 \times 45 \mathrm{~s}, 200 \mathrm{~W})$ and the pellet was discarded. The homogenate was centrifuged at $20000 \mathrm{~g}$ for $30 \mathrm{~min}$ at $4{ }^{\circ} \mathrm{C}$. The supernatant solution was concentrated to a final protein concentration of $15-20 \mathrm{mg} \mathrm{ml}^{-1}$ using an Amicon B-15 macrosolute concentration device, and stored in $25 \mu \mathrm{l}$ portions at $-20^{\circ} \mathrm{C}$. Protein was determined by the Lowry method using bovine serum albumin as a standard. Isoelectric focusing was done using $1 \%$ IEF-agarose and Pharmalyte 3-10 (both from Pharmacia), in accordance with the supplier's guidelines.

DNA procedures. The Ri plasmid was isolated from $A$. rhizogenes strain TR 105 according to the procedures of Currier \& Nester (1976). The BglII (New England Biolabs) restricted pattern of the authentic Ri plasmid was compared to that of the putative Ri plasmid in the A. radiobacter transconjugant (LH16), using a modification of the mini-plasmid preparation procedure of Silhavy et al. (1984). Electrophoresis of digested DNA was done according to David et al. (1980). Other DNA procedures, used on parent and transconjugant bacteria, were done as described by Strobel et al. (1985).

Electron microscopy. The techniques and procedures used for transmission electron microscopy and scanning electron microscopy of nodules and root segments were those described by Strobel et al. (1985). At least six nodules produced on clover roots by each bacterial strain were examined.

Plant growth and analyses. Seeds of clover (Trifolium pratense L. cv. Redland) were surface disinfected and rinsed in sterile distilled $\mathrm{H}_{2} \mathrm{O}$ according to the procedures previously used for alfalfa (Strobel et al., 1985). After the seeds had germinated they were inoculated with bacteria and planted in sterilized medium grade white sand in conetainers, which were placed in racks in a growth chamber. The racks and the chamber had been thoroughly scrubbed with Chlorox followed by $70 \%(\mathrm{v} / \mathrm{v})$ ethanol solutions. The emerging plants were watered on alternate days with a sterilized Hoagland solution minus nitrogen and grown with $12 \mathrm{~h}$ darkness at $22^{\circ} \mathrm{C}$ and $12 \mathrm{~h} \mathrm{light}$ at $27^{\circ} \mathrm{C}$ with a light intensity of $170 \mu \mathrm{E} \mathrm{m}^{-2} \mathrm{~s}^{-1}$. The numbers of nodules of all sizes on each plant were counted after $30 \mathrm{~d}$. Between 12 and 20 plants were used in each treatment category and the experiments were replicated at least three times. Kjeldahl analysis was done on groups of five to seven whole dried plants. Root-initiating ability of various bacteria was tested on root discs of various plants prepared and inoculated according to Moore et al. (1979).

\section{RESULTS AND DISCUSSION}

\section{Ri plasmid transfer}

We used $A$. rhizogenes strain BL311 as a donor of the Ri plasmid to $R$. trifolii LH3. Strain BL311 carries an Ri plasmid mutant with elevated transferability due to a Tn 5 insertion. There was no detectable transfer of the Ri plasmid from $A$. rhizogenes TR105 to $R$. trifolii LH3. 
(a)

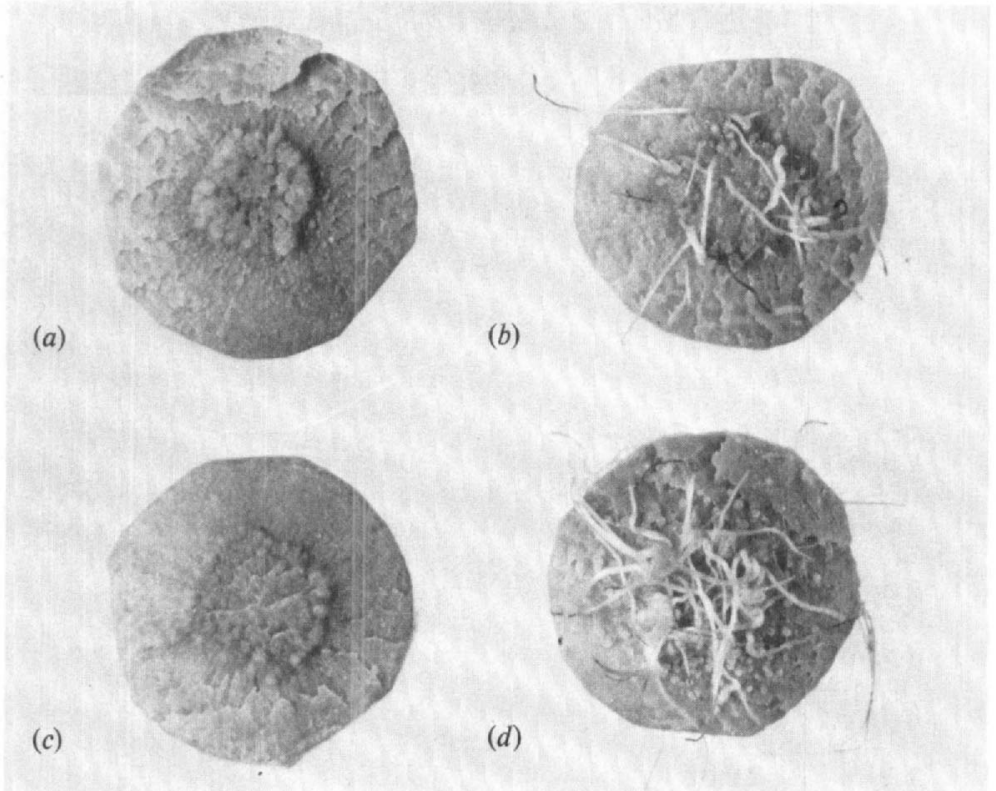

Fig. 1. Carrot root discs inoculated with (a) R. trifolii 2067 (same response given with $R$. trifolii LH3, parent bacterium), (b) $R$. trifolii (pRi) transconjugant (LH11), (c) A. radiobacter NT1 (parent) and (d) $A$. radiobacter $(\mathrm{pRi})$ transconjugant (LH16). The transconjugants were prepared and inoculated onto the discs as described in Methods.

Furthermore, under the conditions of these mating experiments, no spontaneous antibioticresistant mutants arose.

When strain BL311 was mated with $R$. trifolii LH3, transconjugants were obtained at a frequency of $10^{-4}$ to $10^{-5}$ per parental bacterium. Banding patterns obtained after isoelectric focusing of soluble proteins and gel separation of EcoRI digests of total DNA confirmed that the transconjugants possessed the genetic background of $R$. trifolii (data not shown). Likewise, when the $R$. trifolii transconjugant LH11 was mated with $A$. radiobacter NT1 (the frequency of plasmid transfer was $10^{-3}$ per parental bacterium), the transconjugant (LH16) possessed the same gross protein and $E c o$ RI restriction banding patterns as $A$. radiobacter NT1. Furthermore, a plasmid was isolated from the $A$. radiobacter transconjugant $\mathrm{LH} 16$ which possessed the same gross $B g / \mathrm{II}$ restriction pattern as that given with the authentic $\mathrm{Ri}$ plasmid. The results showed that successful transfer of the Ri plasmid had occurred from $A$. rhizogenes BL311 to $R$. trifolii $\mathrm{LH} 3$, and from $R$. trifolii LH11 to $A$. radiobacter NT1, resulting in $A$. radiobacter LH16. Southern blotting techniques, using labelled $\mathrm{Ri}$ plasmid as a probe, also confirmed that all of the $\mathrm{Ri}$ plasmid was successfully transferred to each of these recipient bacteria (data not shown). Therefore, $A$. rhizogenes BL311 can serve as an effective transfer vector of the Ri plasmid to species of Rhizobium other than $R$. meliloti. The efficiency of transfer, however, is about an order of magnitude lower in the case of $R$. trifolii than $R$. meliloti.

\section{Root induction}

Both the wild-type $A$. rhizogenes strain TR 105 and the plasmid-transfer mutant $A$. rhizogenes BL311 caused root proliferation in carrot, rutabaga, turnip, sweep potato and parsnip. However, in contrast to the $R$. meliloti (pRi) transconjugant (Strobel et al., 1985), the $R$. trifolii (pRi) transconjugant also caused root proliferation in all of the fleshy dicotyledonous plants that were tested (for example, see Fig. 1). Thus, the rooting characteristics of the Ri plasmid are expressed in $R$. trifolii, but not in $R$. meliloti, a totally unexpected result. As expected, the $A$. radiobacter NT1 (pRi) transconjugant (LH16), prepared by mating $A$. trifolii LH11 with $A$. radiobacter NT1, expressed the rooting characteristic of the $\mathrm{Ri}$ plasmid on all of the plants listed above (for example, see Fig. 1). 
Table 2. Growth chamber experiments with clover

The conditions were $12 \mathrm{~h}$ darkness at $22^{\circ} \mathrm{C}$ and $12 \mathrm{~h}$ light at $27^{\circ} \mathrm{C}$ with a light intensity of $170 \mu \mathrm{E} \mathrm{m}^{-2} \mathrm{~s}^{-1}$. The plants were watered on alternate days with sterile Hoagland's solution minus a nitrogen source. With the exception of LH12 and 'no cells' the data are means of three independent experiments, with at least $12-20$ plants per treatment. Means followed by the same letters are not significantly different at $P \leqslant 0.05$ as judged by an LSD multiple comparisons procedure. This analysis was preceded by an analysis of variance which reached a significance at the $P<0.01$ level for nodulation and $P<0.05$ for total $\mathrm{N}$ per plant. The SEM was 0.81 for nodulation and 0.01 for total $\mathrm{N}$ per plant.

\section{Organism}

R. trifolii wild-type (2067)

R. trifolii parent (LH3)

Mixed inoculation:

R. trifolii (2067) plus

$R$. trifolii transconjugant (LHI1)

R. trifolii

transconjugant (LH11-Ro)

R. trifolii ( $\mathrm{pRi})$

transconjugant (LH1I)

R. trifolii (pRi)

transconjugant (LH12)

A. rhizogenes TR105

(pRiTR105-2:: Tn5) (BL311)

A. radiobacter NT1

(pRiTR105-2::Tn5) (LH16)

No cells

$\begin{array}{cc}\begin{array}{c}\text { No. of nodules } \\ \text { per plant }\end{array} & \begin{array}{c}\text { Total N per plant } \\ \text { (mg) }\end{array} \\ 14.6^{\mathrm{a}} & 1.12^{\mathrm{d}} \\ 14.5^{\mathrm{a}} & 1.02^{\mathrm{d}} \\ & \\ 17.7^{\mathrm{b}} & 0.91^{\mathrm{d}} \\ 21.5^{\mathrm{c}} & 0.39^{\mathrm{e}} \\ 0 & 0.075^{*} \\ 0 & 0.08^{*} \\ 0 & 0.085^{*} \\ 0 & 0.068^{*} \\ 0 & 0.05^{*}\end{array}$

* These results were not included in the statistical analysis because the treatments produced no nodules and did not result in biological $\mathrm{N}_{2}$ fixation.

\section{Nodulation and nitrogen fixation}

R. trifolii (pRi) transconjugants LH11 or LH12 did not nodulate clover roots, whereas wildtype $R$. trifolii 2067 or $R$. trifolii LH3 $\left(\operatorname{Rif}^{\mathrm{r}} \operatorname{Str}^{\mathrm{r}}\right.$ ) did (Table 2). However, in a preliminary test, four plants of 20 developed numerous small nodules on their roots after having been inoculated with $R$. trifolii ( $\mathrm{pRi}$ ) transconjugant LH11. The organism in these small nodules was isolated on YM medium containing rifampicin, streptomycin and kanamycin and was designated LH11Ro. It apparently arose by spontaneous mutation and consistently produced significantly more nodules per plant than any of the other rhizobia tested; however, significantly less $\mathrm{N}_{2}$ was fixed by these plants than by plants inoculated with $R$. trifolii strains 2067, LH16, or 2067 and LH11 (Table 2). There seemed to be no question that strain LH11-Ro was an $R$. trifolii (pRi) transconjugant since it was consistently isolated (in $80-100 \%$ of cases) from the small nodules on medium containing three antibiotics with few, if any, contaminants. No bacterial growth was observed on this medium when nodules from plants inoculated with strain 2067 were placed on it. Furthermore, LH11-Ro caused root formation in all of the dicotyledonous plants tested, in a manner and rate comparable to LH11. When LH11-Ro was mated with $A$. radiobacter NT1, using the agrobacterium selective medium containing $500 \mu \mathrm{g}$ kanamycin $\mathrm{ml}^{-1}$, transconjugants were obtained that caused rooting on the dicotyledonous plant species previously mentioned. This suggested that if a mutation had occurred in LH11 to yield LH11-Ro, this had not affected the rooting activity of the Ri plasmid since it was successfully transferred back to $A$. radiobacter without any noticeable effect on its biological activity. Additional work is needed to characterize LH11-Ro.

It should also be mentioned that there was some difficulty in keeping the 'no cell' treatments free of nodulating bacteria during the plant tests, and quite often plants in this group became nodulated even though the strictly aseptic conditions were kept. On some occasions minor cross contamination between the treatments (i.e. 1-5\%) was observed, and this was taken into consideration. 


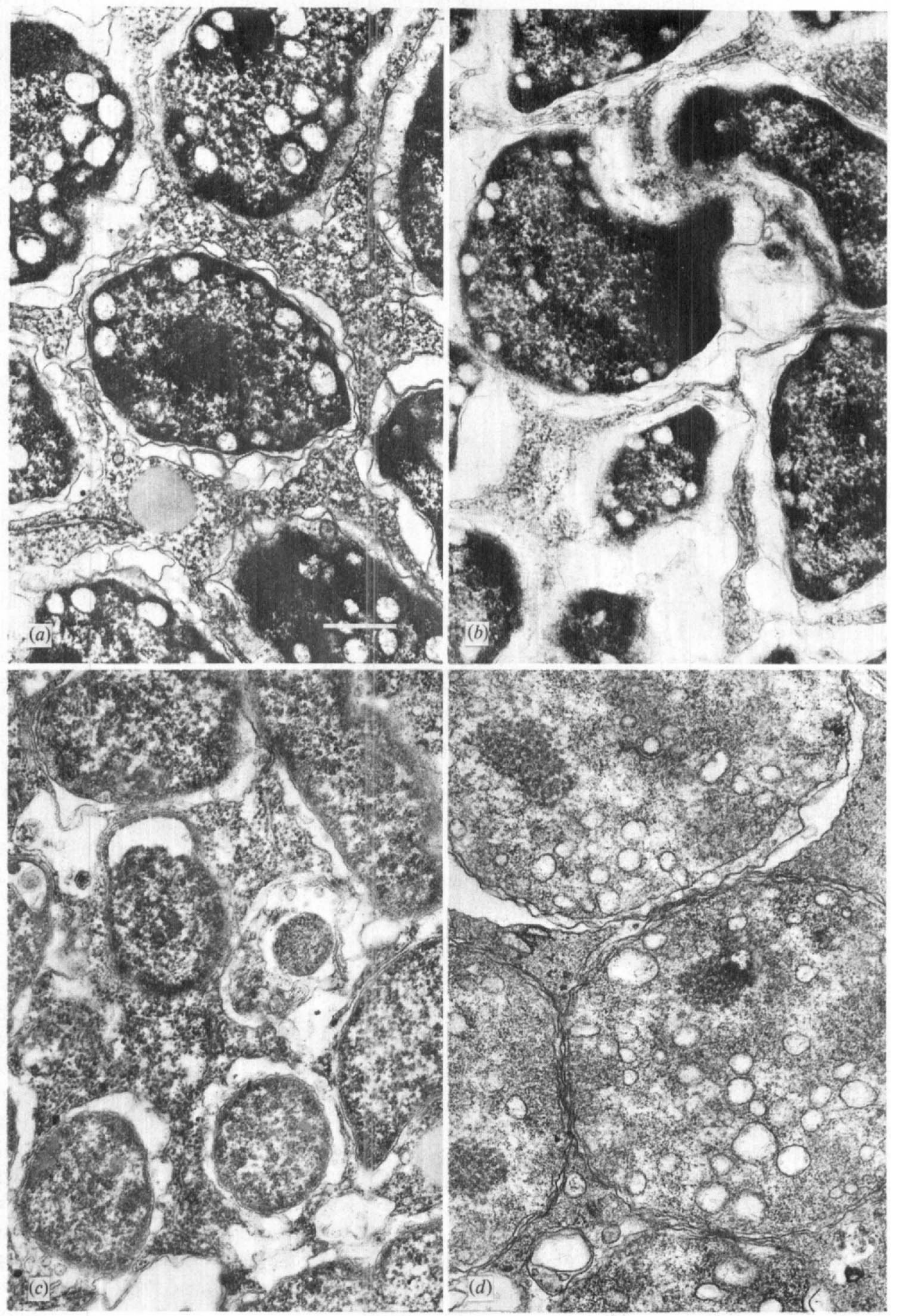

Fig. 2. Electron micrographs of bacteroids in representative nodules from clover plants treated with $(a)$ $R$. trifolii 2067 (wild-type), (b) R. trifolii LH3 (parent bacterium), (c) mutant $R$. trifolii (pRi) transconjugant (LH1 1-Ro) and (d) both $R$. trifolii 2067 and $R$. trifolii (pRi) transconjugant (LH11). Note that the electron transparent granules (probably poly $\beta$-hydroxybutyrate) visible in $(a),(b)$ and $(d)$ are absent in (c). Bar, $0.5 \mu \mathrm{m}$. 
These results on nodulation with $R$. trifolii ( $\mathrm{pRi}$ ) transconjugants are quite different from those observed with $R$. meliloti (Strobel et al., 1985). The $R$. meliloti (pRi) transconjugants consistently produced more nodules than wild-type $R$. meliloti, and this apparently resulted in more $\mathrm{N}_{2}$ fixed. However, when transconjugant strain LH11 was mix-inoculated with wild-type $R$. trifolii, nodulation was greater than that with wild-type alone (Table 2). The transconjugant strain could be isolated from about $50 \%$ of these surface disinfected nodules. Although this observation is interesting, we have no good explanation for the effect.

As expected, no nodules were produced on any of the plants treated with the Agrobacterium strains, or on untreated plants when free of contaminating bacteria. Furthermore, no $\mathrm{N}_{2}$ was fixed in any of these cases (Table 2).

As is true for the R. meliloti transconjugants (Strobel et al., 1985), it seems highly unlikely that we selected, by the single colony technique, a strain of $R$. trifolii that is not capable of nodulating clover, since both LH11 and LH12 behaved in an identical manner. Furthermore, putative pRi transconjugants of $R$. trifolii 2063 , made in the same way as described in this report, also failed to nodulate clover; this is in extreme contrast to the wild-type bacterium (G. A. Strobel, unpublished).

\section{Morphological and cytological effects}

No differences were observed by scanning electron microscopy between the nodules produced by mutant $R$. trifolii (pRi) transconjugant LH11-Ro and the nodules produced by either the wildtype $R$. trifolii 2067 or the $R$. trifolii parent (LH3), except that the nodules produced by LH11-Ro were generally about half the size of those produced by 2067 or LH3. Examination of photographs made by transmission electron microscopy showed that there were gross structural differences between the bacteroids in the nodules produced by the mutant transconjugant LH11Ro and the other $R$. trifolii strains used as inoculants, i.e. parent strain LH3, wild-type strain 2067 and the mixed inoculant, 2067 plus transconjugant LH11. Numerous electron transparent polyhydroxybutyrate storage deposits, which are generally a characteristic feature of nodules produced by rhizobia (Newcomb, 1981; Jordan \& Allen, 1974), were observed in the bacteroids of the rhizobia that caused nodulation, except for the bacteroids of LH11-Ro, where they were absent (Fig. 2). A general decrease in $\mathrm{N}_{2}$ fixation by LH11-Ro seemed to manifest itself in the small size of the nodules that the bacterium produced, and in the small capacity for storage of an energy source by the bacteroids. However, co-inoculation of LH11 with the wild-type bacterium resulted in significantly more nodules than with the wild-type alone, and the nodules again appeared to have normal ultrastructural characteristics (Table 2, Fig. 2).

\section{General observations}

Both $R$. meliloti and $R$. trifolii are considered to be fast-growing species of rhizobia. However, when representative strains of each of these organisms carry and maintain the Ri plasmid they behave differently to each other. When carrying the Ri plasmid, $R$. meliloti enhances nodulation and fixes more $\mathrm{N}_{2}$, but does not express the root-inducing effects of the plasmid, while $R$. trifolii does not nodulate its host, but is capable of causing rooting on the fleshy roots of several dicotyledonous plants. However, spontaneous mutants of the $R$. trifolii (pRi) transconjugant may arise which cause numerous small nodules to form on clover, but $\mathrm{N}_{2}$ fixation by these nodules is significantly decreased when compared to the wild-type. Thus, it appears that the expression of the Ri plasmid in Rhizobium spp. is under the control of either the bacterial genome, or its endogenous plasmids, or both. To date, the Ri plasmid has not been transferred to any of the slow-growing rhizobia. We have shown that many biological consequences can result from the $\mathrm{Ri}$ plasmid transfer to rhizobium, from increased nodulation and $\mathrm{N}_{2}$ fixation to no nodulation whatever, and it seems that there is no method by which we can predict the outcome of such a transfer.

The authors acknowledge the financial support of AID grant DPE-5542-G-SS, the Montana Agricultural Experiment Station and the Danish Agricultural and Veterinary Research Council. The technical help of L. Harrison and D. Hagle is greatly appreciated. Dr R. Lund kindly provided statistical analyses. 


\section{REFERENCES}

Currier, T. C. \& Nester, E. W. (1976). Evidence for diverse types of large plasmids in tumor-inducing strains of Agrobacterium. Journal of Bacteriology 126, 157-165.

Davis, R. W., Botstein, D. \& Rotem, J. E. (1980). Advanced Bacterial Genetics. Cold Spring Harbor, NY: Cold Spring Harbor Laboratory.

JoRDAN, D. C. \& AlleN, O. N. (1974). Rhizobium. In Bergey's Manual of Determinative Bacteriology, 8th edn, pp. 262-264. Edited by R. E. Buchanan \& N. E. Gibbons. Baltimore: Williams \& Wilkins.

Moore, L. W., Warren, G. \& Strobel, G. A. (1979). Involvement of a plasmid in the hairy root disease of plants caused by Agrobacterium rhizogenes. Plasmid 2, 617-626.

Newcomв, W. (1981). Nodule morphogenesis and differentiation. In Biology of the Rhizobiaceae (International Review of Cytology, Suppl. 13), pp. 247-298. Edited by K. L. Giles \& A. G. Atherly. New York: Academic Press.
Silhavy, T. J., Berman, M. L. \& Enquist, L. W. (1984). Experiments with Gene Fusions. Cold Spring Harbor, NY: Cold Spring Harbor Laboratory.

Strobel, G. A., Lam, B., Harrison, L., Hess, W. M. \& LAM, S. (1985). Introduction of the hairy root plasmid into Rhizobium meliloti results in increased nodulation on its host. Journal of General Microbiology 131, 355-361.

Strobel, G. A. \& Nachmias, A. (1985). Agrobacterium rhizogenes promotes the initial growth of bare root stock almond. Journal of General Microbiology 131, 1245-1249.

White, F. F. \& Nester, E. W. (1980a). Hairy root plasmid encodes virulence traits in Agrobacterium rhizogenes. Journal of Bacteriolog. 141, 1134-1141.

WhITE, F. F. \& NesTER, E. W. (1980 b). Relationship of plasmids responsible for hairy root and crown gall tumorigenicity. Journal of Bacteriology 144, 710-720. 